\title{
Interaction of Mercury(II) with Humic Substances from the Rio Negro (Amazonas State, Brazil) by Means of an Ion Exchange Procedure
}

\author{
Julio C. Rocha ${ }^{a^{*}}$, Jeosadaque J. de Sene ${ }^{a}$, Peter Burba ${ }^{b}$, \\ and Dieter Klockow ${ }^{b}$ \\ ${ }^{a}$ Institute of Chemistry, UNESP, C.P. 355, 14800-900 Araraquara - SP, Brazil; \\ ${ }^{b}$ Institute of Spectrochemistry and Applied Spectroscopy (ISAS), PO Box 101352, \\ D-44013 Dortmund, Germany
}

Received: June 30, 1997

\begin{abstract}
Neste estudo investigou-se a complexação do íon mercúrio (II) por substâncias húmicas aquáticas extraídas (utilizando-se resina XAD 8) do Rio Negro - AM - Brasil. Frações lábeis/inertes de complexos de $\mathrm{Hg}$ (II)-SH foram caracterizadas por processo de troca iônica usando-se as técnicas em batelada e em coluna e resina Chelite $\mathrm{S}$. Este coletor apresenta coeficientes de distribuição, $\mathrm{K}_{\mathrm{d}}$, em relação a $\mathrm{Hg}(\mathrm{II})$ da ordem de $10^{4}$ diminuindo, contudo, em casos de pequenas razões $\mathrm{Hg}(\mathrm{II}) / \mathrm{SH}$ $(<0.1 \mu \mathrm{g} \mathrm{Hg}(\mathrm{II}) / \mathrm{mg} \mathrm{SH}$ ). A influência de diferentes parâmetros (razão de $\mathrm{Hg}$ (II)/SH, pH, tempo de contato, tempo de complexação) relevantes na complexação de $\mathrm{Hg}(\mathrm{II})$ em ambientes aquáticos foi avaliada. A labilidade de $\mathrm{Hg}(\mathrm{II})$ em SH dissolvida é influenciada, principalmente, pela razão de massa $\mathrm{Hg}(\mathrm{II}) / \mathrm{SH}$ e pelo tempo de complexação das espécies $\mathrm{Hg}$ (II)-SH formadas. Assim, no caso de baixa concentração de $\mathrm{Hg}$ (II) em relação à concentração de $\mathrm{SH}$, lentos processos de transformação das espécies $\mathrm{Hg}(\mathrm{II})-\mathrm{SH}$ recentemente formadas diminuem a labilidade causando recuperações abaixo da porcentagem total de $\mathrm{Hg}$ (II) ligado à $\mathrm{SH}$.
\end{abstract}

The aquatic humic substances (HS) investigated in this study with respect to their binding capability towards mercury(II) were isolated from the river Rio Negro, Amazonas State - Brazil, by means of the adsorbent XAD 8. Labile/inert fractions of inorganic $\mathrm{Hg}$ (II) complexes formed with these HS were characterized using an ion-exchange batch and column technique, respectively, based on Chelite $\mathrm{S}$. This collector exhibits high $\mathrm{Hg}(\mathrm{II})$ distribution coefficients, $\mathrm{K}_{\mathrm{d}}$, up to the order of $10^{4}$ decreasing, however, in the case of small $\mathrm{Hg}(\mathrm{II}) / \mathrm{HS}$ ratios $(<0.1 \mu \mathrm{g} \mathrm{Hg}(\mathrm{II}) / \mathrm{mg} \mathrm{HS})$. The influence of different complexation parameters (ratio of $\mathrm{Hg}(\mathrm{II}) / \mathrm{HS}$, $\mathrm{pH}$, contact time, complexing time) relevant for $\mathrm{Hg}$ (II) binding in aquatic environments was assessed. $\mathrm{The} \mathrm{Hg}$ (II) lability in dissolved $\mathrm{HS}$ is mainly influenced by the mass ratio of $\mathrm{Hg}$ (II)/ $\mathrm{HS}$ and the ageing of $\mathrm{Hg}$ (II)-HS species formed. This is particularly obvious in the case of low $\mathrm{Hg}$ (II) loading of HS where slow transformation processes of freshly formed $\mathrm{Hg}(\mathrm{II})$-HS species significantly decrease their lability, leading to incomplete recoveries $(<20 \%)$ of the total $\mathrm{Hg}$ (II) bound to HS.

Keywords: Mercury(II) speciation, ion exchange, aquatic humic substances, Rio Negro

\section{Introduction}

The Rio Negro is one the two source rivers of the Amazonas. In accordance with data hitherto published ${ }^{1}$, the main humic acid flux to the Amazon River system results from the Rio Negro which contributes 2.5 times the input of the Rio Solimões. The major mass of organic carbon dissolved in tropical aquatic environments, particularly in dark-colored rivers ("Rio Negro") of the Amazon basin, is concentrated in humic substances (HS). Due to a broad spectrum of binding sites, HS are generally able to interact 
with heavy metal ions in aquatic systems ${ }^{2}$, e.g. in surface waters, sediments and soil leakage waters. Therefore, deposition, hydrogeochemical cycles and bioavailability of environmentally problematic metals like mercury, are supposed to be strongly dependent on the nature and the thermodynamic stability of their macromolecular species formed with $\mathrm{HS}^{3}$. In aerobic natural waters, $\mathrm{Hg}$ (II) can complex with inorganic ligands (e.g. $\mathrm{Cl}-, \mathrm{OH}-)$, interact with dissolved organic carbon (DOC), or adsorb to particulate matter ${ }^{4}$.

In the Brazilian Amazon region goldmining has become a major activity, using mercury for amalgamation ${ }^{5,6}$. During this process, considerable amounts of mercury escape into the flowing river. The total loss of $\mathrm{Hg}$ has been estimated to be $1.32 \mathrm{~kg} \mathrm{Hg} / \mathrm{kg} \mathrm{Au}$, from which $45 \%$ are released into rivers and $55 \%$ into the atmosphere ${ }^{7,8}$. The pollution of the Amazon River afluents by mercury from gold mining is an important aspect to be considered for environmental protection measures ${ }^{9}$. Therefore studies of mercury species in aquatic HS, particularly on the lability/inertness of mercury(II) in humic-rich waters, are of increasing interest.

The present study concentrates on interactions between HS (isolated by the collector XAD 8$)^{10}$ from Rio Negro (RN) water, and inorganic $\mathrm{Hg}(\mathrm{II})$, the predominant species besides $\mathrm{CH}_{3}-\mathrm{Hg}^{+}$in natural waters ${ }^{11}$. For the discrimination between labile and inert $\mathrm{Hg}$ (II) bound to HS the chelating ion exchanger Chelite S (SERVA Company) containing immobilized thiophenol as functional groups was chosen ${ }^{12}$. Both, the degree and the kinetics of separation were assumed to be useful parameters for the operational characterization of the lability of traces of $\mathrm{Hg}$ (II) bound to HS-RN under defined conditions (e.g. $\mathrm{pH}$, HS concentration, ratio of $\mathrm{Hg}(\mathrm{II}) / \mathrm{HS}-\mathrm{RN}$, complexing time), in analogy to previous ion-exchange studies with other heavy metal ions ${ }^{13-15}$.

\section{Experimental}

\section{Chemicals and reagents}

All reagents used were of high-purity grade unless otherwise stated. Diluted acids and bases necessary for HS isolation were prepared from 30\% hydrochloric acid (suprapur, Merck AG) and sodium hydroxide-monohydrate (suprapur Merck AG), respectively, employing high-purity water (Milli-Q system, Millipore), The adsorbent XAD 8 p.a. (Serva Feinbiochemica) required for the isolation of aquatic $\mathrm{HS}$ was purified by successive soaking with 0.5 $\mathrm{mol} / \mathrm{L} \mathrm{HCl}, 0.5 \mathrm{~mol} / \mathrm{L} \mathrm{NaOH}$ and methanol p.a. (24 h, each) prior to use. The chelating ion exchanger Chelite $\mathrm{S}$ used for the distinction of labile/inert $\mathrm{Hg}$ (II) species was precleaned by successive soaking with $10 \mathrm{~mol} / \mathrm{L} \mathrm{HCl}$ p.a.

\section{HS isolation by XAD 8}

The HS investigated in this study were isolated from the Rio Negro at Tarumanzinho, Amazonas State, Brazil. For this purpose, a mixed water sample $(50 \mathrm{~L}$, continuously collected within $1 \mathrm{~h}$ ) was filtrated through $0.45 \mu \mathrm{m}$ cellulose-based membranes and acidified by concentrated $\mathrm{HCl}$ to $\mathrm{pH}$ 2.0. Then, HS from the acidified sample were isolated on the collector XAD 8. After elution with $0.1 \mathrm{~mol} / \mathrm{L}$ $\mathrm{NaOH}$, the obtained HS concentrate (containing $2.5 \mathrm{mg} / \mathrm{ml}$ DOC equivalent to about $5 \mathrm{mg} / \mathrm{mL} \mathrm{HS}$ ) was neutralized and stored in a refrigerator at $\pm 4{ }^{\circ} \mathrm{C}$.

\section{Determination of dissolved organic carbon (DOC)}

The DOC in water samples and HS concentrates was evaluated by its oxidation to carbon dioxide subsequently measured with an IR-analyzer (Shimadzu TOC 2000).

\section{Hg(II) selective ion exchangers}

The separation of reactive $\mathrm{Hg}$ (II) fractions from dissolved HS was carried out by employing the thiophenolcontaining ion exchanger Chelite S. Both, batch and flow procedure were used for this purpose ${ }^{13}$. $\mathrm{Hg}$ (II) retained on Chelite $\mathrm{S}$ could be eluted quantitatively with $10 \mathrm{~mol} / \mathrm{L} \mathrm{HCl}$.

\section{Batch procedure}

The HS containing samples $(50 \mathrm{~mL}$, each) were pretreated up to $24 \mathrm{~h}$ with traces of $\mathrm{Hg}$ (II) keeping constant the chosen $\mathrm{pH}$ value. Then, $0.1 \mathrm{~g}$ of Chelite $\mathrm{S}$ was added under mechanical stirring. After the reaction time chosen, the collector was isolated on a filter paper pre-cleaned with 2 $\mathrm{mol} / \mathrm{L} \mathrm{HCl}$. Then $\mathrm{Hg}(\mathrm{II})$ bound to the collector was eluted with $2.5 \mathrm{~mL}$ of $10 \mathrm{~mol} / \mathrm{L} \mathrm{HCl}$.

\section{Flow procedure}

Small glass columns (5 mm i.d.) filled with Chelite S (0.25-0.5 g) were inserted into a small flow system consisting of a peristaltic pump (Gilson 2) and a three-way valve for sample introduction, cleaned with $10 \mathrm{~mol} / \mathrm{L} \mathrm{HCl}$ and washed with high-purity water. The contact time between the exchanger phase and the flowing sample was changed by varying the flow rate from 0.1 to $20 \mathrm{~mL} / \mathrm{min}$.

\section{"Ageing" process}

Several HS solutions ( $25 \mathrm{~mL}$, each) were spiked with $10 \mu \mathrm{g}$ of $\mathrm{Hg}(\mathrm{II})$ and conditioned at $\mathrm{pH} 5.0$ and $25^{\circ} \mathrm{C}$ in the dark for different periods of time ( 0.25 to $240 \mathrm{~h})$. Afterwards, labile $\mathrm{Hg}$ (II) fractions of these samples were removed and collected according to the described flow procedure.

\section{Determination of $\mathrm{Hg}(\mathrm{II})$}

$\mathrm{Hg}$ (II) determinations in solutions were carried out by means of conventional cold-vapor atomic absorption spec- 
trometry (CVAAS), using the sodium borohydrite method $^{16}$. Manufacturer recommendations where taken into account for the Varian-Intralab AA 1475 spectrometer used. The detection limit ( $3 \mathrm{~s}$ ) was $0.1 \mathrm{ng} / \mathrm{mL} \mathrm{Hg}$ (II) and the relative standard deviation $5 \%(2 \mathrm{ng} / \mathrm{mL} \mathrm{Hg}(\mathrm{II}), \mathrm{n}=10)$.

\section{Results and Discussions}

\section{HS in the Rio Negro River}

The aquatic humic matter transported in huge amounts from the Rio Negro into the Amazon River has already been the subject of various studies ${ }^{1,17,18}$. Accordingly, the Rio Negro exhibits DOC values in the range of $10-12 \mathrm{mg} / \mathrm{L}$ of $\mathrm{C}$ which are mainly to be attributed to dissolved HS, thus representing a flux of approximately $320-350 \mathrm{~kg} \mathrm{HS} / \mathrm{s}$ in this river ${ }^{1}$. The Rio Negro HS, "HS-RN", used in this study for interaction experiments with $\mathrm{Hg}(\mathrm{II})$, was isolated from a mixed water sample $(50 \mathrm{~L})$ by means of the "standardized" XAD 8 procedure ${ }^{10}$. Relevant parameters of this water sample with its HS-RN are summarized in Table 1 showing that about $65 \%$ of the measured DOC $(12 \mathrm{mg} / \mathrm{L})$ was collected by the adsorbent XAD 8, assuming a 50\% $\mathrm{C}$-content of HS. The complexation capacity of HS-RN towards $\mathrm{Cu}$ (II) ions as determined with a $\mathrm{Cu}$ (II)-selective electrode yielded the relatively high value of $2.8 \mathrm{mmol}$ $\mathrm{Cu}(\mathrm{II}) / \mathrm{g} \mathrm{C}$.

The concentrations of trace metals were characterized in the Rio Negro water and the HS-RN isolated. They range from the analytical detection limits $[$ e.g. $\mathrm{Cd}(<0.1 \mu / \mathrm{L}$ and $<4 \mu / \mathrm{g}), \operatorname{Co}(<0.1 \mu / \mathrm{L}$, and $<8 \mu / \mathrm{g}) \mathrm{Cr}(<0.1$ and $<8 \mu / \mathrm{g}$, $)$ to considerable contents at the $\mathrm{mg} / \mathrm{L}$ level $[\mathrm{Al}(150 \mu / \mathrm{L}$ and $260 \mu / \mathrm{g}), \mathrm{Fe}(1850 \mu / \mathrm{L}$ and $450 \mu / \mathrm{g})]$. As expected, the HS isolation from the acidified sample solution $(\mathrm{pH} 2.0)$ causes an extensive remobilization of the metal ions naturally bound to HS, except for a considerable fraction of acid-inert $\mathrm{Al}$ and $\mathrm{Fe}$.

\section{$\mathrm{Hg}(\mathrm{II})$ separation from $\mathrm{HS}$ with Chelite S: Influence of $\mathrm{Hg}$ (II) loading and $\mathrm{pH}$-value}

The discrimination between exchange-labile and -inert metal fractions in HS by chelate-forming ion-exchanger requires collectors of high selectivity forming strongly immobilized metal complexes ${ }^{19,20}$. Under this condition the separation capability of the chosen collector Chelite S were studied in slightly acidic and neutral solutions of mercury(II)-loaded HS-RN (pH 5 and 7) and characterized by means of the $\mathrm{Hg}$ (II) distribution coefficients, $\mathrm{K}_{\mathrm{d}}$, $(\mathrm{mL} / \mathrm{g})$, as a function of an increasing mercury(II) loading of HS-RN, $\mu \mathrm{g} \mathrm{Hg}(\mathrm{II}) / \mathrm{mg}$ HS-RN (see Fig. 1). Accordingly, the $\mathrm{Hg}(\mathrm{II})$ distribution coefficients $\mathrm{K}_{\mathrm{d}}$ on Chelite $\mathrm{S}$ exhibit a strong dependance on the $\mathrm{Hg}$ (II) loading of the studied HS. In the case of very small $\mathrm{Hg}(\mathrm{II})$ loadings $(<0.1 \mu \mathrm{g}$ $\mathrm{Hg}(\mathrm{II}) / \mathrm{mg}$ HS-RN) Chelite S merely exhibits $\mathrm{K}_{\mathrm{d}}$ values of $10^{2}(\mathrm{~mL} / \mathrm{g})$, requiring a multistage column procedure for quantitative remobilisation of $\mathrm{Hg}$ (II) ions from their binding sites in HS-RN. In the case of increased $\mathrm{Hg}$ (II) loadings $\left(>1 \mathrm{~g} \mathrm{Hg}(\mathrm{II}) / \mathrm{mg}\right.$ HS-RN) $\mathrm{K}_{\mathrm{d}}$ values of about $10^{4}(\mathrm{~mL} / \mathrm{g})$ are available enabling the separation of labile $\mathrm{Hg}$ (II) even by means of a single-stage batch procedure.

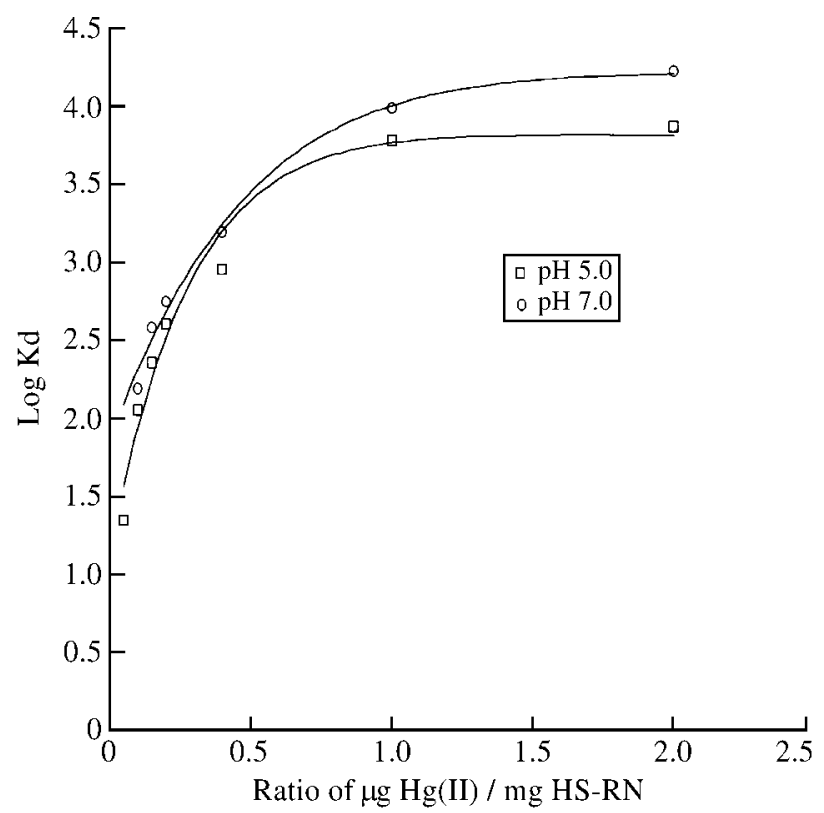

Figure 1. $\mathrm{Hg}(\mathrm{II})$ distribution coefficients, $\mathrm{K}_{\mathrm{d}}$, on Chelite $\mathrm{S}$ as a function of the ratio $\mu \mathrm{g} g(\mathrm{II}) / \mathrm{mg} \mathrm{HS}-\mathrm{RN}$ at different $\mathrm{pH}$ values. Spiking of HS-RN: $50 \mathrm{~mL}$ sample, $0.05-1.0 \mathrm{mg} / \mathrm{ml} \mathrm{HS}-\mathrm{RN}, 5 \mu \mathrm{g} \mathrm{Hg}(\mathrm{II})$; equilibration for $24 \mathrm{~h}$, then $24 \mathrm{~h}$ in contact with $0.1 \mathrm{~g}$ Chelite $\mathrm{S}$; batch procedure.

Table 1. Characterization of HS from Rio Negro (HS-RN) waters of Tarumanzinho collected in February 95.

\begin{tabular}{lc}
\hline $\mathrm{pH}$ & 6.5 \\
Conductivity & $58 \mu \mathrm{S} \mathrm{cm}^{-1}$ \\
Temperature & $27^{\circ} \mathrm{C}$ \\
Dissolved organic carbon & $12 \mathrm{mg} / \mathrm{L} \mathrm{of} \mathrm{C}$ \\
HS-RN (isolated by XAD 8) & $8,25 \mathrm{mg} / \mathrm{L}$ \\
Complexation capacity of HS-RN & $2.8 \mathrm{mmol} \mathrm{Cu}(\mathrm{II}) / \mathrm{g} \mathrm{C}$ \\
$\mathrm{Hg}$ & $<0.01 \mu / \mathrm{L}$ (water) and $<0.4 \mu / \mathrm{g}$ (in HS-RN) \\
\hline
\end{tabular}


Considerable mercury losses $(>5 \%)$ by partial reduction of $\mathrm{Hg}(\mathrm{II})$ to $\mathrm{Hg}(0)$ in the presence of dissolved HS as previously reported ${ }^{21}$ could not be observed in the case of HS-RN.

\section{$\mathrm{Hg}(I I)$ separation with Chelite $\mathrm{S}$ : Influence of the contact time}

The influence of the contact time and HS concentration on the $\mathrm{Hg}$ (II) separation from solutions of HS-RN by means of the Chelite $\mathrm{S}$ batch procedure was studied in detail as shown in Fig. 2. As can be seen, nearly quantitative $\mathrm{Hg}$ (II) recovery is obtained within $15 \mathrm{~min}$ in the case of a high ratio of $\mathrm{Hg}(\mathrm{II}) / \mathrm{HS}$, whereas a decrease of this ratio reduces the recovery rate and delays considerably the time period necessary for equilibration.

\section{Influence of the ratio $\mathrm{Hg}(\mathrm{II}) / \mathrm{HS}$ on the $\mathrm{Hg}(\mathrm{II})$-lability}

In accordance with ${ }^{22}$ both the thermodynamic and the kinetic stability, the HS/metal complexes are highly dependent on the ratio of metal loading to the complexation capacity of HS. At low metal loading, metal ions are preferentially bound to functional groups which provide formation of complexes of maximum thermodynamic stability $^{23}$. The opposite behaviour can be expected in the case of increasing metal loading, leading to successively increased lability and metal recovery. The results of a respective experiment with $\mathrm{Hg}$ (II) and HS-RN are shown in Fig. 3. Accordingly, $\mathrm{Hg}$ (II) can be quantitatively recovered at $>0.5 \mu \mathrm{g} \mathrm{Hg}(\mathrm{II}) / \mathrm{mg}$ HS-RN showing evidence for only labile species. In contrast, a recovery of $<10 \%$ is observed at $<0.05 \mu \mathrm{g} \mathrm{Hg}(\mathrm{II}) / \mathrm{mg}$ HS-RN. Such an ion-exchange procedure, however, is not able to distinguish between

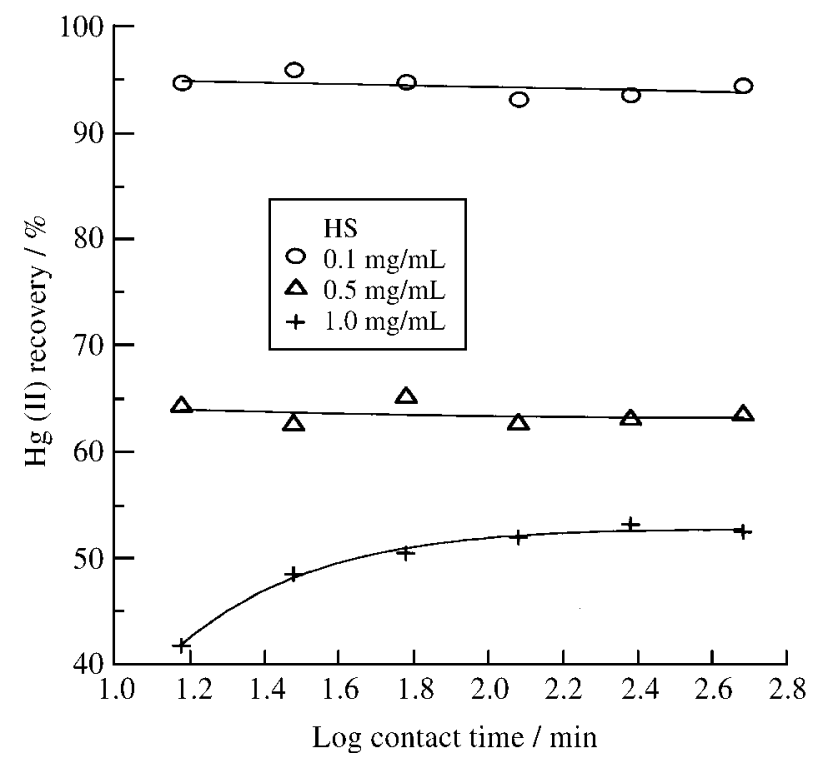

Figure 2. Influence of contact time and HS concentration on the recovery of $\mathrm{Hg}$ (II) from HS. Spiking of HS-RN: $50 \mathrm{~mL}$ sample, $5 \mu \mathrm{g} \mathrm{Hg}(\mathrm{II}), \mathrm{pH}$ 5.0, equilibration for $24 \mathrm{~h}$ with $0.1 \mathrm{~g}$ Chelite $\mathrm{S}$; batch procedure. thermodynamic and kinetic inertness of the metal species studied.

The influence of loading and contact time on the $\mathrm{Hg}$ (II) separation from HS-RN by using the Chelite S flow procedure is shown in Fig. 4. The separation curves, exhibited there, also demonstrate that high $\mathrm{Hg}$ (II) loadings of HS result in highest lability and recovery.

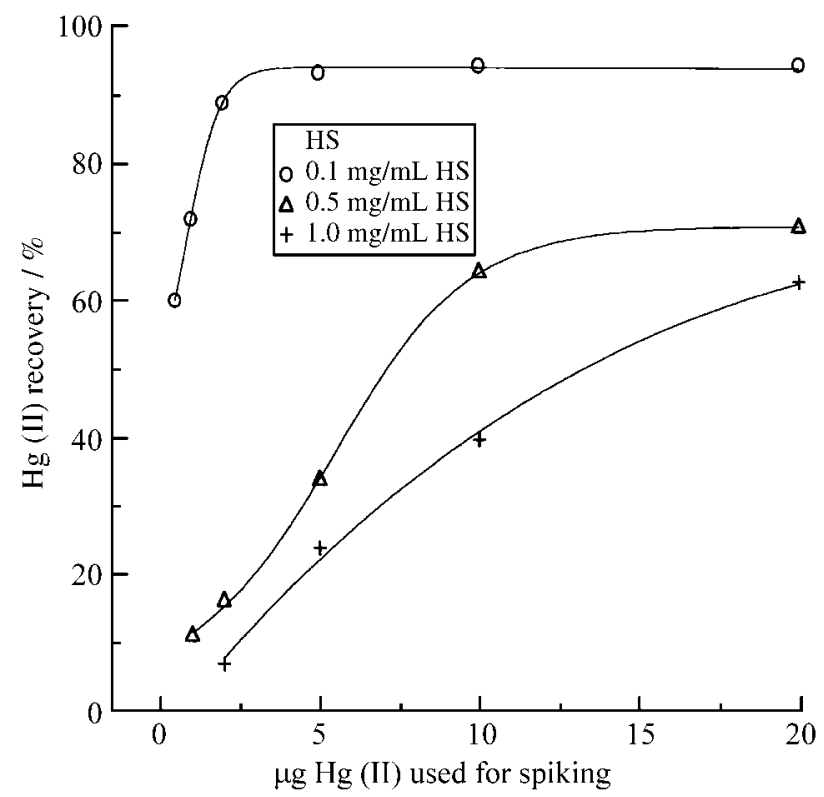

Figure 3. Influence of the loading degree on the lability of $\mathrm{Hg}(\mathrm{II})$ bound to HS. Spiking of HS: $50 \mathrm{~mL}$ sample, $0.1-1.0 \mathrm{mg} / \mathrm{mL}$ HS-RN, $1-20 \mu \mathrm{g}$ $\mathrm{Hg}(\mathrm{II}), \mathrm{pH} 5.0$, equilibration for $24 \mathrm{~h}$ with $0.1 \mathrm{~g}$ Chelite $\mathrm{S}$; batch procedure.

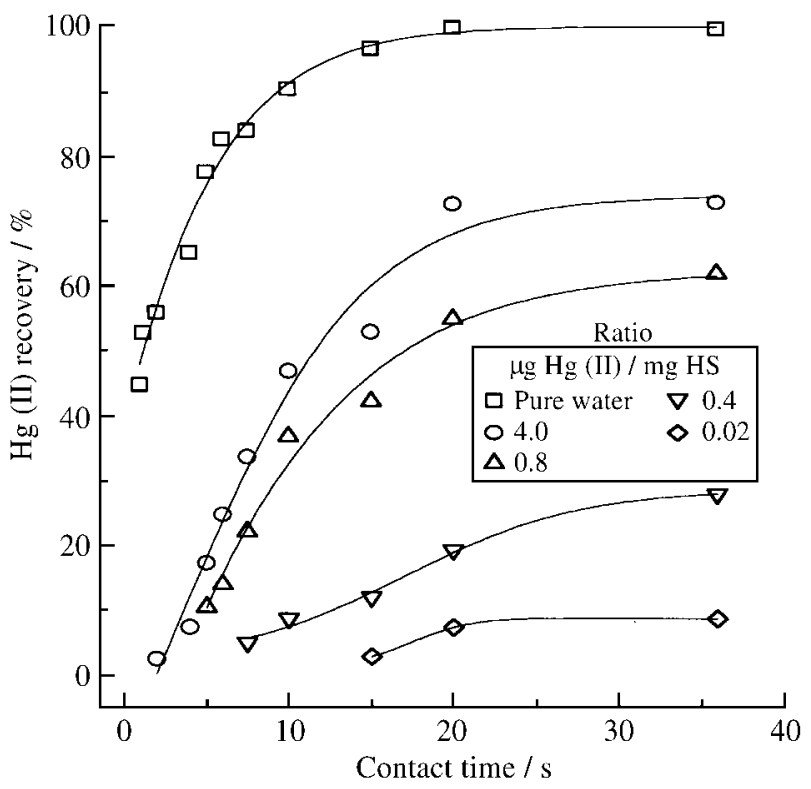

Figure 4. Separation of $\mathrm{Hg}$ (II) from $\mathrm{HS}$ as a function of the contact time at different $\mathrm{Hg}$ (II) loadings. Flow procedure: column filled with $0.2 \mathrm{~g}$ Chelite S; 0.1-1.0 mg/mL HS-RN, 0.02-0.4 g/mL Hg(II), 25 mL sample, pH 5.0, complexing time $24 \mathrm{~h}$. Without HS: $25 \mathrm{~mL}$ sample, $0.4 \mu \mathrm{g} / \mathrm{mL}$ $\mathrm{Hg}(\mathrm{II}), \mathrm{pH} 5.0,0.5 \mathrm{~mol} / \mathrm{L} \mathrm{NaCl}$. 


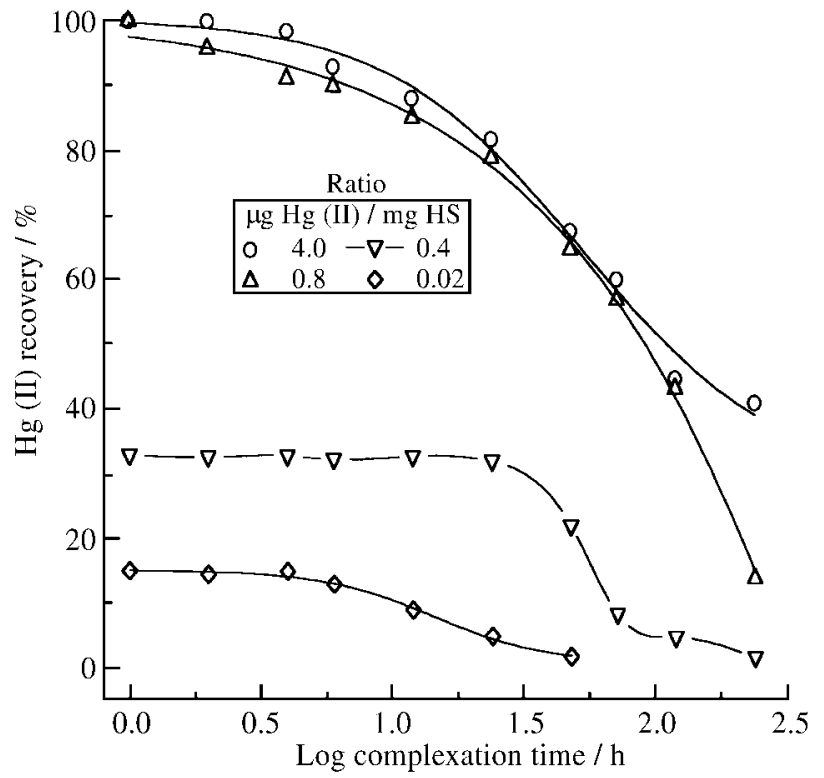

Figure 5. Influence of "ageing" on the lability of $\mathrm{Hg}(\mathrm{II})$-HS species at different $\mathrm{Hg}$ (II) loadings. Flow procedure: column filled with $0.2 \mathrm{~g}$ Chelite $\mathrm{S}$; 0.1-1.0 mg/mL HS-RN, 0.02-0.4 $\mu \mathrm{g} / \mathrm{mL} \mathrm{Hg(II),} 25 \mathrm{~mL}$ sample, $\mathrm{pH} 5.0$, contact time: $35 \mathrm{~s}$.

Another environmentally important parameter influencing the reactivity of metals in HS may be potential transformation processes ("ageing") of the formed macromolecular metal species ${ }^{15}$. It can be supposed that metal ions freshly bound to HS are preferably complexed by functional groups easily accessible in such macromolecules, whereas "aged" metal loadings increasingly occupy inner-sphere binding sites. The influence of such "ageing" processes on the lability of $\mathrm{Hg}(\mathrm{II})$ ions bound to HS-RN is demonstrated in Fig. 5. The separation curves for $\mathrm{Hg}$ (II) recovery show that the increase of the complexation time retards the $\mathrm{Hg}$ (II) exchange with Chelite $\mathrm{S}$ to a larger and larger extent, even when the $\mathrm{Hg}$ (II) loading is relatively high (> $1 \mu \mathrm{g} \mathrm{Hg}$ (II)/mg HS-RN). After 10 days of "ageing", the resin Chelite S collects only $40 \%$ of the bound $\mathrm{Hg}$ (II) in the case of $4 \mu \mathrm{g} \mathrm{Hg}(\mathrm{II}) / \mathrm{mg}$ HS-RN. Low $\mathrm{Hg}$ (II) loadings of the studied HS $(0.02 \mu \mathrm{g} \mathrm{Hg}(\mathrm{II}) / \mathrm{mg}$ HS-RN) appear to be practically inert.

\section{Conclusions}

HS are suggested to strongly bind mercury in aquatic and terrestrial systems forming predominantly inert macromolecular species, presumably due to thio-containing functional groups ${ }^{24,25}$.

Therefore, the thiophenol group containing ion exchanger Chelite $\mathrm{S}$ was chosen as a competitor for HS-RN and proved to be a very efficient collector for $\mathrm{Hg}(\mathrm{II})$ providing both, fast separation kinetics and high distribution coefficients $\mathrm{K}_{\mathrm{d}}$ for traces of dissolved $\mathrm{Hg}$ (II), even in the presence of relatively high HS concentrations. Thus, under standardized conditions, the suggested procedure can be utilized for a reproduceable operational characterization of labile $\mathrm{Hg}(\mathrm{II})$ in $\mathrm{HS}$.

It was shown that the $\mathrm{Hg}$ (II) lability in HS isolated from the Rio Negro is strongly influenced by the ratio of $\mathrm{Hg}(\mathrm{II}) / \mathrm{HS}-\mathrm{RN}$ and by "ageing" of the $\mathrm{Hg}(\mathrm{II})-\mathrm{HS}-\mathrm{RN}$ species formed. Obviously, in the case of a small $\mathrm{Hg}$ (II) loading continuous transformation processes occur, strongly decreasing the $\mathrm{Hg}$ (II) "availability" in HS-RN. These results are comparable to those previously obtained with HS from other aquatic environments ${ }^{12}$ and suggest that $\mathrm{Hg}(\mathrm{II})$ in concentrations as found in Rio Negro water (see Table 2) and even at greater concentration is efficiently made "unavailable" in HS-rich environments.

\section{Acknowledgments}

The authors are indebted to FAPESP / CNPq (Brazil) and DAAD (Germany) for financial support of J.C.R. and fellowship of J.J.S.

\section{References}

1.Ertel, J.R.; Hedges, J.I.; Devol, A.H.; Richey, J.E.; Ribeiro, M.N.G. Limnol. Oceanogr. 1986, 31, 739.

2. Aiken, G.R.; MacKnight, D.M.; Wershaw, R.L.; MacCarthy, P.; Eds.; Humic substances in soil, sediment and water (geochemistry, isolation and characterization); John Wiley \& Sons; New York, 1984.

3. Buffle, J. In Complexation reactions in aquatic systems: an analytical approach; Horwood; Chichester, 1988, p. 195.

4. Driscoll, C.T.; Yan, C.; Schofield, C.L.; Munson, R.K.; Holsapple, J.H. Environ. Sci. Technol. 1994, 28, 136A.

5. Lacerda, L.D. Química Nova 1997, 20, 196.

6. Lacerda, L.D.; Salomons, W. In Mercury from gold and silver minining: a chemical time bomb?; Springer, Germany, 1997.

7.Pfeiffer, W.C.; Lacerda, L.D. Environ. Technol. Letters 1988, 9, 325.

8. Martinelli, L.A.; Ferreira, J.R.; Forsberg, B.R.; Victoria, R.L. Ambio 1988, 17, 252.

9. Malm, O.; Pfeiffer, W.C.; Souza, C.M.M.; Reuther, R. Ambio 1990, 19, 11.

10. Aiken, G.R. In Humic substances in soil, sediment and water (geochemistry, isolation and characterization); Aiken, G.R.; MacKnight, D.M.; Wershaw, R.L.; MacCarthy, P., Eds; John Wiley \& Sons; New York, 1985, p. 363.

11. Wilken, R.D. Fresenius J. Anal. Chem. 1992, 342, 795.

12. Rocha, J.C.; Burba, P.; Klockow, D.; Eclética Química 1993, 18, 83.

13. Burba, P.; Rocha, J.C.; Klockow, D. Fresenius J. Anal. Chem. 1994, 349, 800.

14. Burba, P. Fresenius J. Anal. Chem. 1994, 348, 301. 
15. Rocha, J.C.; Toscano, I.A.S.; Burba, P. Talanta 1997, 44, 69.

16. Jackwerth, E.; Willmer, P.G.; Höhn, R.; Berndt, H. At. Abs. Newsl. 1979, 18, 66.

17. Leenheer, J.A. Acta Amazonica 1980, 10, 513.

18. Richey, J.E.; Wilhelm, R.S.; McClain, E.M.; Victoria, R.L.; Melack, J.M. Ciência e Cultura, 1997, 49, 98.

19. Buffle, J. In Complexation reactions in aquatic systems: an analytical approach; Horwood; Chichester, 1988, p. 600.

20. Perdue, E.M. In Metal speciation. Theory analysis and applications; Kramer, J.R.; Allen, H.E.; Eds.; Lewis Pub; Chelsea, 1988, p. 135.
21. Matthiessen, A. Fresenius J. Anal. Chem. 1996, 354, 747.

22. Buffle, J.; Tessier, A.; Haerdi, W. In Complexation of trace metals in natural waters; Kramer, C.J.M.; Duinker, J.C.; Eds.; The Hague Boston Lancaster; Nijhoff/Junk, 1984, p. 301.

23. Burba, P.; Rocha, J.C.; Schulte, A. Fresenius J. Anal. Chem. 1993, 346, 414.

24. Sibley, T.M.; Morgan, I.I. In Proc. Int. Conf. Heavy Metals Environm.; Hutchinson, T.; Ed.; University of Toronto; Ontario, 1975, p. 319.

25. Wallschläger, D.; Desai, M.V.M.; Wilken, R.D. Water Air Soil Pollut. 1996, 89, 1.

FAPESP helped in meeting the publication costs of this article 